\title{
Genetic defects in GH synthesis and secretion
}

\author{
G Bona ${ }^{1}$, R Paracchini ${ }^{1}$, M Giordano ${ }^{2}$ and $\mathrm{P}$ Momigliano-Richiardi ${ }^{2}$ \\ ${ }^{1}$ Clinica Pediatrica and ${ }^{2}$ Laboratorio di Genetica Umana, Dipartimento di Scienze Mediche, Università del Piemonte Orientale 'Amedeo Avogadro', \\ Corso Mazzini 18, 28100 Novara, Italy \\ (Correspondence should be addressed to G Bona; Email: gianni.bona@maggioreosp.novara.it)
}

\begin{abstract}
Growth hormone $(\mathrm{GH})$ is a multifunctional hormone produced in the anterior pituitary that promotes postnatal growth of skeletal and soft tissues. GH secretion and release are complex phenomena depending on several intrinsic and extrinsic factors modulating the release of two hypothalamic hormones, GH releasing hormone and somatostatin. Any genetic or acquired disorder that impairs GH secretion or action causes a pathological phenotype characterized by harmonic short stature with isolated GH deficiency (IGHD) or combined pituitary hormone deficiency (CPHD). In this article we report current knowledge about the genetic basis of IGHD and CPHD.
\end{abstract}

European Journal of Endocrinology 151 S3-S9

\section{Introduction}

Growth hormone $(\mathrm{GH})$ is a multifunctional hormone produced in the anterior pituitary that promotes postnatal growth of skeletal and soft tissues. Over the last twenty years several genes implicated in growth regulation have been identified including genes encoding the growth hormone itself, the $\mathrm{GH}$ releasing hormone (GHRH) and its receptor (GHRHR), and pituitary transcriptional factors (Pit-1, Prop-1, Hesx-1, Lhx-3, Lhx-4).

\section{Isolated GH deficiency (IGHD)}

Short stature associated with IGHD has been estimated to occur in 1 in 4000-10000 new-borns $(1,2)$. Most cases are sporadic, but $3-30 \%$ have an affected relative, suggesting a genetic etiology of the disease. Sporadic IGHD cases, which represent the majority, are believed to result mainly from environmental cerebral insults or developmental anomalies. However, de novo mutations in the $\mathrm{GH}$ encoding gene (GH1) have been detected in patients with sporadic $\operatorname{IGHD}(3,4)$.

\section{GH1 gene}

GH1 is the most extensively studied gene in IGHD. It includes 5 exons and 4 introns for a total of $1800 \mathrm{bp}$ and it is located on chromosome $17 \mathrm{q} 23$ within a $66 \mathrm{~Kb}$ cluster including five highly homologous (92-98\%) genes of which GH1 is expressed in the pituitary, CSH-1, CSH-2 and GH-V in the placental syncytiotrophoblast cells, and CSH-P is a pseudogene.

Mutations in the GH1 gene have been detected in about $12.5 \%$ of familial and $10 \%$ of sporadic IGHD and include deletions of the entire gene and nonsense mutations in the most severe forms, and splicing mutations in the milder forms (5). These mutations cause different types of IGHD classified as IA, IB, II and III on the basis of the severity and the mode of inheritance (Table 1). The most severe form of IGHD (IGHD IA), characterized by the total absence of GH, has an autosomic recessive mode of inheritance and the patients carry gross deletions removing the entire GH1 or, in a few cases, nonsense mutations leading to a premature stop codon. The milder forms (characterized by a very low but detectable amount of GH and responsiveness to exogenous $\mathrm{GH}$ therapy) include IGHD IB, autosomic recessive, (that is the most common form) and IGHD II, autosomic dominant. In these forms patients carry nucleotide substitutions affecting mRNA splicing. IGHD III is inherited as an $\mathrm{X}$-linked recessive trait, but its molecular basis is, to date, unknown $(6,7)$.

The GH1 coding sequence is highly conserved. In contrast, the GH1 promoter exhibits an unusually high level of nucleotide variations (8). There are some indications that promoter polymorphisms influence GH secretion and height (9) but none of them has, to date, been clearly associated with IGHD. In a study including 21 Italian IGHD patients, all the promoter nucleotide substitutions were detected with comparable frequencies in the patients and in normal controls with the possible exception of $-1 \mathrm{~T}$ that was increased in the patients with a borderline statistical significance (10).

In most IGHD patients no GH1 mutation is found. Since several factors take part in GH secretion, it is likely that genetic forms of GH deficiency can result from mutations in other genes such as GHRH, GHRHR, PIT-1, PROP-1, HESX1, LHX3, and LHX4.

\section{GHRHR gene}

The GHRHR gene consists of 13 exons spanning a $15 \mathrm{~Kb}$ DNA segment on chromosome 7p15 (11). 
Table 1 Genetically determined IGHD.

\begin{tabular}{llll}
\hline Type & Mode of inheritance & Features & Etiology \\
\hline IGHD-IA & Autosomical recessive & Total deficiency & GH-1 deletions \\
& & Development of anti-GH antibodies & Nonsense mutations \\
IGHD-IB & Autosomical recessive & Partial deficiency & Splicing mutations \\
IGHD-II & Autosomical dominant & Partial deficiency & Missense and splicing mutations \\
IGHD-III & X-linked & Partial deficiency \pm agammaglobulinemia & Unknown \\
\hline
\end{tabular}

Eleven different mutations have been detected to date in the human GHRHR gene in homozygous or combined heterozygous patients with IGHD IB (Fig. 1) $(12-14)$. These mutations make the GHRHR functionally inactive and cause a characteristic phenotype called 'Dwarfism of Sindh', inherited as an autosomic recessive trait and characterized by very low GH levels and severe short stature. Patients show good responsiveness and immunological tolerance to exogenous GH therapy. Preliminary results indicate that mutations in the GHRHR gene constitute $10 \%$ of IGHD IB. Mutations in the GHRHR are not limited to the coding sequence. Promoter mutations that impair Pit-1 binding might as well reduce expression of the GHRHR gene. A recent report described a patient with isolated GH deficiency type IB who was heterozygous for a missense mutation (K329E) and an $A \rightarrow C$ transversion (position -124) in one of the two sites of the promoter region binding the pituitaryspecific transcription factor Pit-1 required for GHRHR expression. Functional studies showed that cells transfected with the mutant promoter yielded significantly less luciferase activity than with the wild-type promoter. DNA binding studies confirmed that the $\mathrm{A} \rightarrow \mathrm{C}$ base change markedly reduces DNA binding of the Pit-1 protein (15).

\section{Combined deficiency}

Combined pituitary hormone deficiency (CPHD) denotes impaired production of $\mathrm{GH}$ and one or more of the other five anterior pituitary-derived hormones (thyrotropin (TSH), prolactin (PRL), adrenocorticotropin (ACTH), luteinizing hormone (LH), follicle-stimulating hormone (FSH)).

A great deal has been learned about the genetic causes of CPHD with the discovery of transcriptional activation factors that direct the embryonic development of the anterior pituitary $(16,17)$. Formation and subsequent Rathke's pouch differentiation into the anterior pituitary gland are regulated by the combined action of specific transcription activating factors including Hesx-1, Ptx-1, Ptx-2, Lhx-3, Lhx-4, Prop-1 and Pit-1.

\section{PIT-1 gene}

Pit-1 is a pituitary-specific factor essential for development of somatotrope, lactotrope, and thyrotrope cells in the anterior pituitary and it transactives expression of the genes encoding GH, PRL, and TSH- $\beta$. The human PIT-1 gene, designed as POUF1, is located on chromosome 3p11 (18).

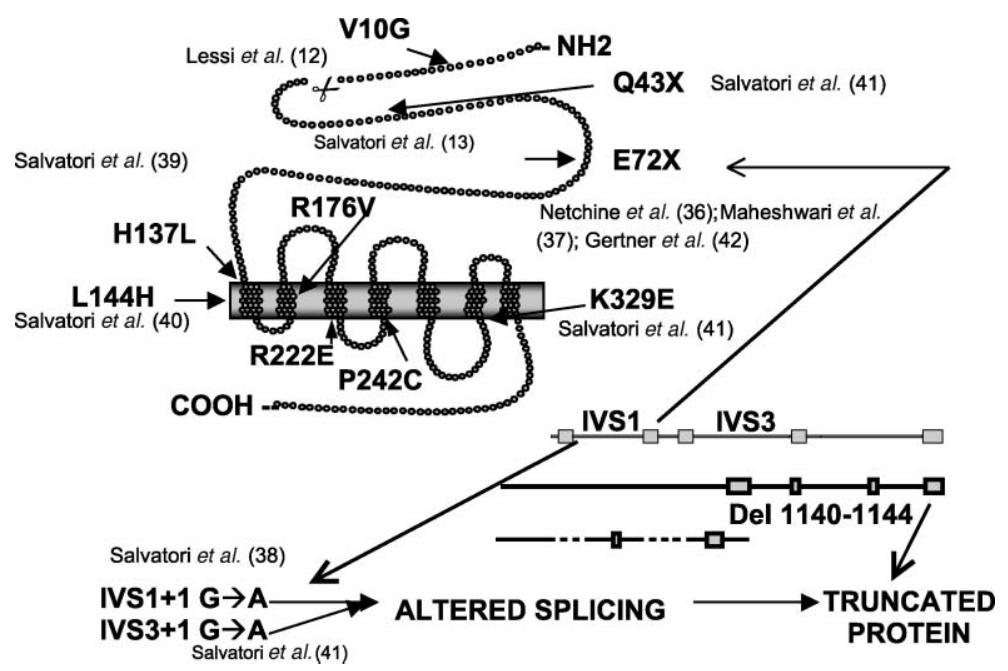

Figure 1 GHRHR structure and known mutations. 
Mutations in the human PIT-1 are responsible for a CPHD with deficiency of GH, PRL or TSH, while the production of ACTH, LH and FSH are preserved. There is phenotypic variability in the degree of CPHD and in the pituitary size of the patient. GH deficiency is generally severe with severe growth retardation and failure to thrive usually diagnosed before the age of two years. There is more variability in the degree of hypothyroidism. Some patients are born with features of cretinism; others are euthyroid at diagnosis and develop mild hypothyroidism during $\mathrm{GH}$ treatment. Although LH and FSH are normal, some patients with PIT-1 abnormalities may experience delayed puberty because of delay in thyroxine or GH treatment. Magnetic resonance imaging shows a moderately hypoplasic pituitary in some patients and a gland of normal shape and size in other subjects (16).

To date, 1 gross deletion and 18 point mutations have been detected in humans (Fig. 2) (16, 19-21). These are mainly located within exons 4 and 6. Most of the mutations alter residues important for DNA binding or the predicted $\alpha$ helical nature of POU-domains; sometimes mutations cause the complete or partial loss of the transcriptional activating function.

\section{PROP-1 gene}

Prophet of Pit-1 gene (PROP-1) maps to chromosome $5 \mathrm{q}$ and encodes a transcription factor involved in the early embryonic pituitary development. It is necessary for expression of Pit-1, for the differentiation of Pit-1dependent cell lineage and for gonadotrope differentiation (22). PROP-1 mutations are the most common causes of genetically determined CPHD (16).

So far, 13 different mutations have been identified within PROP-1 (Table 2) (23). All the mutations control a recessive trait and affect the domain involved in the binding of the transcriptional factor to its cognate

PIT-1

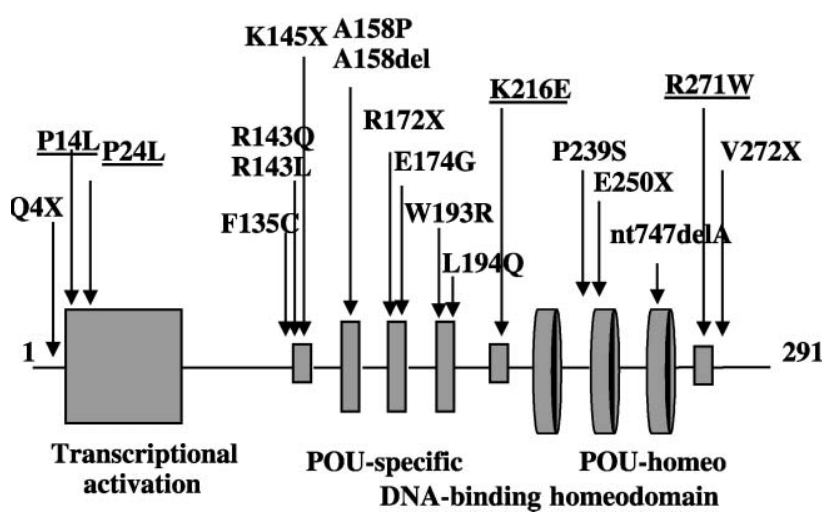

Figure 2 Point mutations of human PIT-1. The underlined mutations are found in the heterozygous state. The others are found in the homozygous or combined heterozygous state.

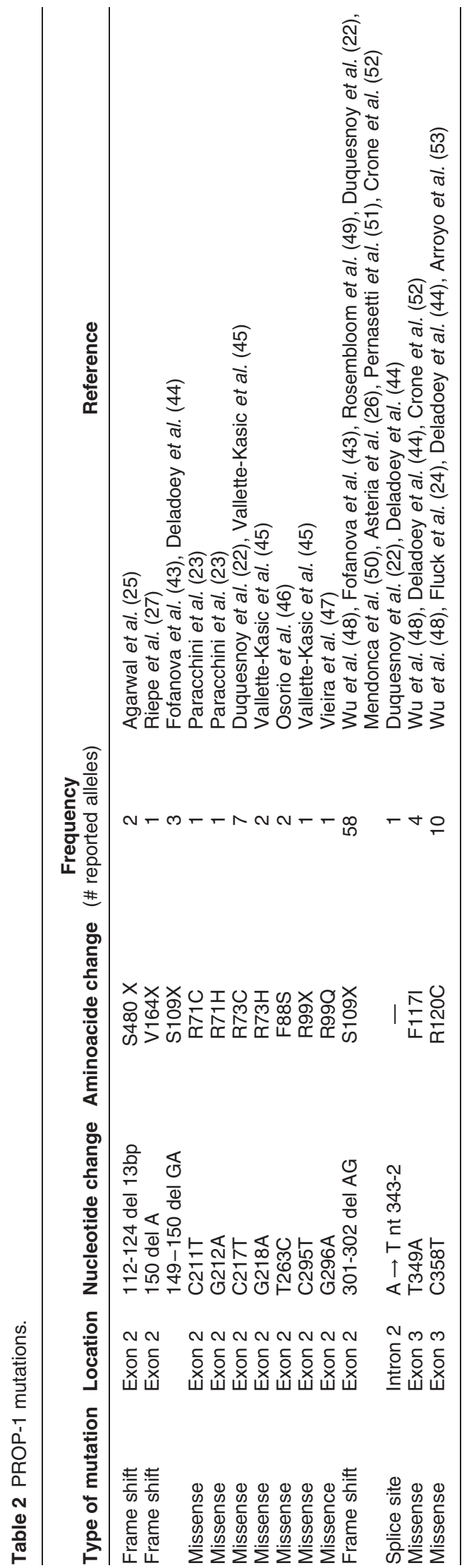


DNA sites. Mutations in PROP-1 have been reported as a cause of CPHD involving GH, PRL, TSH as well as gonadotropins and, occasionally, ACTH. The clinical phenotype associated with PROP-1 mutations varies considerably, especially with respect to the occurrence and the severity of the different pituitary hormone deficiencies. There is no correlation between genotype and phenotype $(16,24)$.

The most consistent presenting feature is growth retardation mainly caused by $\mathrm{GH}$ deficiency - rarely is TSH the first symptom. Most patients fail to enter puberty and show consistently low LH and FSH responses to $\mathrm{LH}$ releasing hormone (LHRH) stimulation. In rare cases, patients may reach spontaneous pubertal development with normal $\mathrm{LH}$ and FSH responses to an LHRH stimulation test, but, in any case, they are destined later to develop hypogonadism (16). A progressive late onset ACTH deficiency that can induce an acute cortisone insufficiency, with risk of shock with advancing age, has been reported in only a few cases. Therefore, a molecular analysis of all subjects affected by CPHD becomes necessary in order to identify patients carrying PROP-1 mutations as they will require a life-long evaluation of the ACTH-adrenal axis $(25,26)$. Phenotypic variability also applies to pituitary size that may be normal, hypoplasic or even enlarged. Most patients have a hypoplasic anterior pituitary; in contrast, there are few reports of patients with PROP-1 mutations and pituitary enlargement. Longitudinal follow-up of these patients showed that the pituitary enlargement was followed by a progressive involution during the second decade of life resulting in pituitary hypoplasia. The pituitary enlargement during early childhood must not be mistaken for craniopharyngioma, pituitary adenoma, dysgerminoma or Rathke's pouch cyst, since pituitary surgery is not indicated in patients with PROP1 mutations (27).

\section{HESX1 gene}

HESX1 is a member of a paired-like class of homeobox genes that maps at locus 3p21.1-21.2 and codes for a transcriptional factor. Its expression is essential for the development of the optic nerve and regulates some of the earliest stages in pituitary development. Mice homozygous for a mutation in Hesx 1 display multiple defects in placodally derived anterior structures including the eye, olfactory epithelium, forebrain and pituitary. This phenotype is similar to the abnormalities observed in the human disorder called septo-optic dysplasia (SOD), a syndromic form of congenital hypopituitarism which is characterized by the triad of pituitary hypoplasia and/or optic nerve hypoplasia and/or agenesis of midline brain structures, including the corpus callosum and septum pellucidum (28). To date, 5 missense mutations in the human HESX1 have been described in individuals with phenotypes ranging from severe SOD to relatively mild CPHD or isolated GH deficiency occasionally associated with undescended/ectopic posterior pituitary (Table 3) $(28-30)$. The milder phenotype is present in heterozygous patients who have inherited the mutation from a healthy parent. Since GH deficiency is the most common manifestation of reduced HESX1 among heterozygous individuals, it will be important to assess the relative contribution of heterozygous HESX1 mutations in patients with sporadic and familial pituitary hypoplasia, in particular with isolated $\mathrm{GH}$ deficiency (29). More recently, a de novo heterozygous mutation (306/307 ins AG) within exon 2 was associated with panhypopituitarism and anterior pituitary hypoplasia, an ectopic posterior pituitary, and left optic nerve hypoplasia in a Japanese patient (31).

\section{LHX3 gene}

LHX3, located at 9q34, encodes a member of the LIM homeodomain family of transcription factors that is critical for both early structural development of the pituitary gland and for the specification and proliferation of the gonadotrope, lactotrope, somatotrope, and thyrotrope pituitary cell lineages. $L h x-3$ knockout mice do not develop a mature pituitary gland and only form a few corticotrope cells. Similarly, a recent report has described two mutations (1 deletion and 1 missense mutation) in the human LHX3 gene that are associated with CPHD characterized by the loss of all but one (adrenocorticotropin) of the five hormones

Table 3 HESX1: Genotype-phenotype correlations.

\begin{tabular}{llll}
\hline No. & \multicolumn{1}{c}{ HESX1 mutation } & \multicolumn{1}{c}{ Endocrine disorder } & \\
\hline $1-1^{\mathrm{a}}$ & $\mathrm{R} 160 \mathrm{X}$ (homoz.) & CPHD & ACC, ONH \\
$1-2^{\mathrm{a}}$ & $\mathrm{R} 160 \mathrm{X}$ (homoz.) & CPHD & ACC, ONH \\
$2-1^{\mathrm{b}}$ & $\mathrm{S} 170 \mathrm{~L}$ (heteroz.) & IGHD & ONH bilateral \\
$2-2^{\mathrm{b}}$ & $\mathrm{S} 170 \mathrm{~L}$ (heteroz.) & IGHD & Normal \\
3 & T181A (heteroz.) & IGHD & Anterior pituitary hypoplasia \\
4 & Q6H (heteroz.) & GH, TSH, LH/FSH deficiency & Anterior pituitary hypoplasia, ectopic posterior pituitary \\
5 & S170L (heteroz.) & IGHD & Anterior pituitary hypoplasia, ectopic posterior pituitary \\
6 & $306 / 307$ ins AG (heteroz.) & CPHD & ONH monolateral, anterior pituitary hypoplasia, ectopic posterior pituitary \\
7 & I26T (homoz.) & CPHD & Anterior pituitary hypoplasia, ectopic posterior pituitary \\
\hline
\end{tabular}

a,b Familiar cases: ${ }^{a}$ family 1 ; ${ }^{b}$ family 2 ; ACC, agenesis of corpum callosum; ONH, optic nerve hypoplasia; homoz., homozygous; heteroz., heterozygous. 
produced in the anterior pituitary resulting in severe growth retardation. Patients also displayed a rigid cervical spine leading to limited head rotation. Two of these patients had a severe pituitary hypoplasia, whereas one patient presented secondarily with an enlarged anterior pituitary (32).

Because LHX3 appears to be important for early formative processes of the developing pituitary gland, it was hypothesized that its mutations would cause ectopic posterior pituitary disease associated with CPHD. However, molecular analysis of LHX3 in patients with posterior pituitary ectopia did not confirm this hypothesis (33).

\section{LHX4 gene}

LHX4 is a LIM-homeobox gene, located at 1q25, which has been shown to regulate, together with the closely related LHX3, proliferation and differentiation of pituitary lineages. In mice loss of both $L h x 3$ and $L h x 4$ causes earlier developmental arrest and only rudimentary pouch formation is detected; Lhx4-deficient pituitaries exhibit correct specification of all five hormone-producing cell types, but the expansion of each specialized cell is reduced dramatically. Lhx 4 mutants have a less severe phenotype than $L h x 3$ mutants; all five anterior cell types are present, albeit severely reduced in number (34).

So far, one mutation is described in human LHX4 responsible of a disease phenotype characterized by short stature and by pituitary and hindbrain (i.e. cerebellar) defects in combination with abnormalities of the sella turcica of the central skull base. Some patients present with GH, TSH and ACTH deficiencies, which is consistent with the hormonal profile of $L h x 4^{-/-}$mice. Nevertheless there is variability in the LHX4 mutant phenotype and one human pedigree includes individuals with CPHD and with IGHD. In addition, some but not all patients display an ectopic pituitary gland posterior hypophysis. Finally, the disease phenotype includes the pointed cerebellar tonsils observed in patients with Arnold Chiari malformation (35).

\section{References}

1 Rivarola MA, Phillips JA III, Migeon CJ, Heinrich JJ \& Hjelle BJ. Phenotypic heterogeneity in familial isolated growth hormone deficiency type IA. Journal of Clinical Endocrinology and Metabolism $19845934-40$.

2 Vimpani GV, Vimpani AF, Lidgard GP, Cameron EHD \& Farquhar JW. Prevalence of severe growth hormone deficiency. British Medical Journal 19772 427-430.

3 Phillips JA III \& Cogan JD. Molecular basis of familial human growth deficiency. Journal of Clinical Endocrinology and Metabolism $19947811-16$.

4 Massa CG, Binder G, Oostijik W, Ranke MB \& Wit JM. De novo mutation of the growth hormone gene: an important cause of congenital isolated growth hormone deficiency? European Journal of Pediatrics $1998157272-275$.
5 Wagner JK, Eblé A, Hindmarsh PC \& Mullis PE. Prevalence of human GH1 gene alterations in patients with isolated growth hormone deficiency. Pediatric Research 199843 105-110.

6 Phillips JA III \& Rimoin DL. Genetic disorders of the pituitary gland. In Principle and Practice of Medical Genetics, edn 3, ch 61, pp 1331-1364. Eds DL Rimoin, JM Connor \& RE Pyeritz. New York: Churchill Livingstone, 1997.

7 Procter AM, Phillips JA III \& Cooper DN. The molecular genetics of growth hormone deficiency. Human Genetics $1998 \quad 103$ 255-272.

8 Giordano M, Marchetti C, Chiorboli E, Bona G \& Richiardi PM. Evidence for gene conversion in the generation of extensive polymorphism in the promoter of the growth hormone gene. Human Genetics $1997100249-255$.

9 Horan M, Millar DS, Hedderich J, Lewis G, Newsway V, Mo N, Fryklund L, Procter AM, Krawczak M \& Cooper DN. Human growth hormone 1 (GH1) gene expression: complex haplotypedependent influence of polymorphic variation in the proximal promoter and locus control region. Human Mutation 200321 $408-423$.

10 Giordano M, Monica L, Paracchini R, Petri A, Ozerkan E, Cavallo L, Wasniewska M, Aimaretti G, Momigliano-Richiardi P \& Bona G. Molecular analysis of the growth hormone gene in isolated growth hormone deficiency: possibile involvement of a promoter polymorphism. Journal of Endocrine Genetics 20012 45-54.

11 Mayo KE. Molecular cloning and expression of a pituitary-specific receptor for growth hormone releasing hormone. Molecular Endocrinology $199261734-1744$.

12 Lessi M, Giordano M, Paracchini R, Petri A, Federico G, Wasniewska M, Pasquino AM, Aimaretti G, Bona G \& Momigliano-Richiardi P. Molecular analysis of the growth hormone releasing hormone receptor (GHRH-R) gene in isolated growth hormone deficiency (IGHD): identification of a likely etiological mutation in the signal peptide. Journal of Endocrine Genetics $20012215-228$.

13 Salvatori R, Fan X, Veldhuis JD \& Couch R. Serum GH response to pharmacological stimuli and physical exercise in two siblings with two new inactivating mutations in the GH-releasing hormone receptor gene. European Journal of Endocrinology $2002 \mathbf{1 4 7}$ $591-596$.

14 Carakushansky M, Whatmore AJ, Clayton PE, Shalet SM, Gleeson HK, Price DA, Levine MA \& Salvatori R.. A new missense mutation in the growth hormone-releasing hormone receptor gene in familial isolated GH deficiency. European Journal of Endocrinology $200314825-30$.

15 Salvatori R, Fan X, Mullis PE, Haile A \& Levine MA. Decreased expression of the GHRH receptor gene due to a mutation in a Pit-1 binding site. Molecular Endocrinology $2002 \quad 16$ $450-458$.

16 Parks JS, Brown MR, Harley DL, Phelps CJ \& Wajnrajch MP. Heritable disorders of pituitary development. Journal of Clinical Endocrinology and Metabolism $1999 \mathbf{8 4} 4362-4370$.

17 Watkins-Chow DE \& Camper SA. How many homeobox genes does it take to make a pituitary gland? TIG $19984284-289$.

18 Andersen B \& Rosenfeld M. POU domain factors in the neuroendocrine system: lesson from development biology provide insights into human disease. Endocrine Review 200122 2-35.

19 McLennan K, Jeske Y, Cotterill A, Cowley D, Penfold J, Jones T, Howard N, Thomsett M \& Choong C. Combined pituitary hormone deficiency in Australian children: clinical and genetic correlates. Clinical Endocrinology $2003 \mathbf{5 8} 785-794$.

20 Hashimoto Y, Cisternino M \& Cohen LE. A novel missense mutation in the Pit-1 gene: evidence for a gene dosage effect. Journal of Clinical Endocrinology and Metabolism $2003 \mathbf{8 8}$ 1241-1247.

21 Salemi S, Besson A, Eblé A, Gallati S, Pfaffle RW \& Mullis PE. New N-terminal locater (Q4ter) within the POUF1-gene (PIT-1) causes recessive combined pituitary hormone deficiency and variable phenotype. Growth Hormone and IGF Research 200313 $264-268$. 
22 Dusquenoy P, Roy A, Dastot F, Ghali I, Teinturier C, Netchine I, Cacheux V, Hafez M, Salah N, Chaussain JL, Goossens M, Bougneres P \& Amselem S. Human Prop-1: cloning mapping, genomic structure. FEBS Letters $1998 \mathbf{4 3 7} 216-220$.

23 Paracchini R, Giordano M, Corrias A, Mellone S, Matarazzo P, Bellone J, Momigliano-Richiardi P \& Bona G. Two new PROP1 gene mutations responsible for compound pituitary hormone deficiency. Clinical Genetics 200364 142-147.

24 Fluck C, Deladoey J, Rutishauser K, Eblé A, Marti U, Wu W \& Mullis PE. Phenotypic variability in familial combined pituitary hormone deficiency caused by a Prop-1 gene mutation resulting in the substitution of Arg $\rightarrow$ Cys at codon 120 (R120C). Journal of Clinical Endocrinology and Metabolism $1998 \mathbf{8 3}$ 3727-3733.

25 Agarwal G, Bhatia V, Cook V \& Thomas PQ. Adrenocorticotropin deficiency in combined pituitary hormone deficiency patients homozygous for a novel PROP1 deletion. Journal of Clinical Endocrinology and Metabolism 200085 4556-4561.

26 Asteria C, Oliveira JHA, Abuchm J \& Beck-Peccoz P. Central hypocortisolism as part of combined pituitary hormone deficiency due to mutations of Prop-1 gene. European Journal of Endocrinology $2000143347-352$.

27 Riepe FG, Partsch CJ, Blankenstein O, Monig H, Pfaffle RW \& Sippel WG. Longitudinal imaging reveals pituitary enlargement preceding hypoplasia in two brothers with combined pituitary attributable to Prop-1 mutations. Journal of Clinical Endocrinology and Metabolism $2001864353-4357$.

28 Dattani MT \& Robinson IC. HESX1 and septo-optic dysplasia. Reviews in Endocrinology and Metabolic Disorders 20023 289-300.

29 Thomas PQ, Dattani MT, Brickman JM, McNay D, Warne G, Zacharin M, Cameron F, Hurst J, Woods K, Dunger D, Stanhope R, Forrest S, Robinson IC \& Beddington RS. Heterozygous HESX1 mutations associated with isolated congenital pituitary hypoplasia and septo-optic dysplasia. Human Molecular Genetics 200110 $39-45$.

30 Carvalho LR, Woods KS, Mendonca BB, Marcal N, Zamparini AL, Stifani S, Brickman JM, Arnhold IJP \& Dattani MT. A homozygous mutation in HESX1 is associated with evolving hypopituitarism due to impaired repressor-corepressor interaction. Journal of Clinical Investigation $20031121192-1201$

31 Tajima T, Hattorri T, Nakajima T, Okuhara K, Sato K, Abe S, Nakae J \& Fujieda K. Sporadic heterozygous frameshift mutation of HESX1 causing pituitary and optic nerve hypoplasia and combined pituitary hormone deficiency in a Japanese patient. Journal of Clinical Endocrinology and Metabolism $2003 \mathbf{8 8} 45-50$.

32 Netchine I, Sobrier ML, Krude H, Schnabel D, Maghnie M, Marcos E, Duriez B, Cacheux V, Moers AV, Goossens M, Gruters A \& Amselem S. Mutations in LHX3 result in a new syndrome revealed by combined pituitary hormone deficiency. Nature Genetics 2000 25 182-186.

33 Sloop KW, Walvoord EC, Showalter AD, Pescovitz OH \& Rhodes SJ. Molecular analysis of LHX3 and Prop-1 in pituitary hormone deficiency with posterior pituitary ectopia. Journal of Clinical Endocrinology and Metabolism 200085 2701-2708.

34 Sheng H, Moriyama K, Yamashita T, Li H, Potter S, Mahon K \& Westphal H. Multistep control of pituitary organogenesis. Science 1997278 1809-1812.

35 Machinis K, Pantel J, Netchine I, Leger J, Camand OJ, Sobrier ML, Dastot-Le Moal F, Duquesnoy P, Abitbol M, Czernichow P \& Amselem S. Syndromic short stature in patients with a germline mutation in the LIM homeobox LHX4. American Journal of Human Genetics $200169961-968$.

36 Netchine I, Talon P, Dastot F, Vitaux F, Goossens M \& Amselem S. Extensive phenotypic analysis of a family with growth hormone (GH) deficiency caused by a mutation in the GH-releasing hormone receptor gene. Journal of Clinical Endocrinology and Metabolism $1998 \mathbf{8 3} 432-436$.

37 Maheshwari HG, Silverman BL, Dupuis J \& Baumann G. Phenotype and genetic analysis of a syndrome caused by an inactivating mutation in the growth hormone-releasing hormone receptor: Dwarfism of Sindh. Journal of Clinical Endocrinology and Metabolism $1998834065-4074$.

38 Salvatori R, Hayashida CY, Aguiar-Oliveira MH, Phillips JA III, Souza AH, Gondo RG, Toledo SP, Conceicao MM, Prince M, Maheshwari HG, Baumann G \& Levine MA. Familial dwarfism due to a novel mutation of the growth hormone-releasing hormone receptor gene. Journal of Clinical Endocrinology and Metabolism $199984917-923$.

39 Salvatori R, Fan X, Phillips JA III, Prince M \& Levine MA. Isolated growth hormone $(\mathrm{GH})$ deficiency due to compound heterozygosity for two new mutations in the GH-releasing hormone receptor gene. Clinical Endocrinology $2001 \mathbf{5 4}$ $681-687$

40 Salvatori R, Fan X, Phillips JA III, Espigares-Martin R, Martin De Lara I, Freeman KL, Plotnick L, Al-Ashwal A \& Levine MA. Three new mutations in the gene for the growth hormone $(\mathrm{GH})$-releasing hormone receptor in familial isolated GH deficiency type IB. Journal of Clinical Endocrinology and Metabolism $2001 \mathbf{8 6}$ $273-279$.

41 Salvatori R, Fan X, Veldhuis JD \& Couch R. Serum GH response to pharmacological stimuli and physical exercise in two siblings with two new inactivating mutations in the GH-releasing hormone receptor gene. European Journal of Endocrinology $2002 \mathbf{1 4 7}$ $591-596$.

42 Gertner JM, Wajnrajch MP \& Leibel RL. Genetic defects in the control of growth hormone secretion. Hormone Research $1998 \mathbf{4 9}$ (Suppl 1) 9-14.

43 Fofanova O, Takamura N, Kinoshita E, Parks JS, Brown MR, Peterkova VA, Evgrafov OV, Goncharov NP, Bulatov AA, Dedov II \& Yamashita S. Compound heterozygous of the PROP1 gene in children with combined pituitary hormone deficiency. Journal of Clinical Endocrinology and Metabolism $1998832601-2603$.

44 Deladoey J, Fluck C, Buyukgebiz A, Kuhlmann BV, Eble A, Hindmarsh PC, Wu W \& Mullis PE. 'Hot spot' in the Prop-1 gene responsible for combined pituitary hormone deficiency. Journal of Clinical Endocrinology and Metabolism $1999 \mathbf{8 4}$ 1645-1649.

45 Vallette-Kasic S, Barlier A, Teinturier C, Diaz A, Manavela M, Berthezene F, Bouchard P, Chaussain JL, Brauner R, PellegriniBouiller I, Jaquet P, Enjalbert A \& Brue T. PROP1 gene screening in patients with multiple pituitary hormone deficiency reveals two sites of hypermutability and high incidence of corticotroph deficiency. Journal of Clinical Endocrinology and Metabolism 2001 $864529-4535$

46 Osorio MGF, Kopp P, Marui S, Lantronico AC, Mendoca BB \& Arnhold I. Combined pituitary hormone deficiency caused by a novel mutation of a conserved residue (F88S) in the homeodomain of PROP1. Journal of Clinical Endocrinology and Metabolism $2000852779-2785$.

47 Vieira TC, Dias da Silva MR, Cerutti JM, Brunner E, Borges M, Arnaldi LT, Kopp P \& Abucham J. Familial combined pituitary hormone deficiency due to a novel mutation R990 in the hot spot region of Prophet of Pit-1 presenting as constitutional growth delay. Journal of Clinical Endocrinology and Metabolism $2003 \mathbf{8 8} 38-44$

48 Wu W, Cogan JD, Pfaffle RW, Dasen JS, Frisch H, O'Connell SM, Flynn SE, Brown MR, Mullis PE, Parks JS, Phillips JA III \& Rosenfeld MG. Mutations in PROP1 cause familial combined pituitary hormone deficiency. Nature Genetics 199818 147-149.

49 Rosenbloom AL, Almonte AS, Brown MR, Baumbach L \& Parks JS. Clinical and biochemical phenotype of familial anterior pituitarism from mutation of the PROP1 gene. Journal of Clinical Endocrinology and Metabolism $1999 \mathbf{8 4}$ 50-57.

50 Mendonca BB, Osorio MG, Latronico AC, Estefan V, Lo LS \& Arnhold IJ. Longitudinal hormonal and pituitary imaging changes in two females with combined pituitary hormone deficiency due to deletion of A301,G302 in the PROP1 gene. Journal of Clinical Endocrinology and Metabolism 199984 942-945. 
51 Pernasetti F, Toledo SP, Vasilyev VV, Hayashida CY, Cogan JD, Ferrari C, Lourenco DM \& Mellon PL. Impaired adrenocorticotropin-adrenal axis in combined pituitary hormone deficiency caused by a two-base pair deletion (301-320delAG) in the Prophet of Pit-1 gene. Journal of Clinical Endocrinology and Metabolism $200085390-397$.

52 Crone J, Pfaffle R, Stobbe H, Prayer D, Gomez I \& Frish H. Familial combined pituitary hormone deficiency caused by PROP1 gene mutation. Hormone Research 200257 120-126.
53 Arroyo A, Pernasetti F, Vasilyev VV, Amato P, Yen SS \& Mellon PL. A unique case of combined hormone deficiency caused by a PROP-1 gene mutation (R120C) associated with normal height and absent puberty. Clinical Endocrinology 200257 283-291.

Received 16 February 2004

Accepted 19 April 2004 